Vol 2 No 1 (2019) 89-110 P-ISSN 2620-295 E-ISSN 2747-0490

DOI: $1047467 /$ elmal.v2i1.316

\title{
Pengaruh Faktor Budaya dan Psikologis Terhadap Keputusan Nasabah Dalam Memilih Bank Syariah Mandiri KCP Tajur
}

\author{
Siti Rahmawati \\ Fakultas Ekonomi \& Bisnis Islam \\ IAI Sahid Bogor \\ sitirahmawati@gmail.com \\ Rio Kartika Supriyatna \\ Masyarakat Ekonomi Syariah (MES) Bogor \\ riokartikasupriyatna@mes-bogoraya.net \\ Muhammad Rizal Arsyad \\ Universitas Gunadarma \\ arsyad.staff@gunadarma.ac.id
}

\begin{abstract}
Islamic banks are financial institutions that have a wide market potential in Indonesia as one of the applications of the Islamic Islamic economic system in realizing Islamic values and teachings that regulate the economic sector of the Ummah. The number of new financial institutions that have emerged as a Sharia Bank as a business entity is demanded to be able to compete with other financial institutions to survive and increase their profitability. One of the supporting factors for the development of Islamic banking is the public's interest in choosing financial institutions. This research was conducted with the aim of analyzing the influence of cultural and psychological factors partially and simultaneously on customer decisions in choosing Islamic banks at Bank Syariah Mandiri KCP Tajur. The data in this study are primary data obtained from distributing questionnaires to 100 customers of Bank Syariah Mandiri KCP Tajur. The analysis model used to test the hypothesis is simple linear regression with the $t$ test method and the f test using the Statistical Package for the Social Sciences (SPSS) program. The results of the t test of this study indicate that cultural factors have no effect on customer decisions in choosing Bank Syariah Mandiri Tajur, while psychological factors affect customer decisions in choosing Bank Syariah Mandiri Tajur. The
\end{abstract}




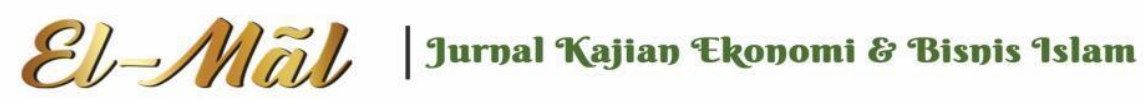

Vol 2 No 1 (2019) 89-110 P-ISSN 2620-295 E-ISSN 2747-0490

DOI: $1047467 /$ elmal.v2i1.316

results of the $F$ test of this study indicate that cultural and psychological factors have a significant effect on customer decisions in choosing Bank Syariah Mandiri Tajur.

Keywords: Culture, Psychology, Customer Decisions

\section{ABSTRAK}

Bank syariah merupakan lembaga keuangan yang memiliki potensi pasar yang cukup luas di Indonesia sebagai salah satu aplikasi dari sistem ekonomi syariah Islam dalam mewujudkan nilai-nilai dan ajaran Islam yang mengatur bidang perekonomian umat. Banyaknya lembaga keuangan baru yang bermunculan Bank Syariah sebagai badan usaha dituntut mampu bersaing dengan lembaga keuangan lainnya untuk tetap bertahan serta dapat meningkatkan profitabilitasnya. Salah satu faktor pendukung perkembangan perbankan syariah adalah minat masyarakat dalam memilih lembaga keuangan. Penelitian ini dilakukan dengan tujuan untuk menganalisis pengaruh faktor budaya dan psikologis secara parsial dan simultan terhadap keputusan nasabah dalam memilih bank syariah pada Bank Syariah Mandiri KCP Tajur. Data dalam penelitian ini merupakan data primer yang diperoleh dari penyebaran kuesioner kepada 100 nasabah Bank Syariah Mandiri KCP Tajur. Model analisis yang digunakan untuk menguji hipotesis adalah regresi linier sederhana dengan metode uji t dan uji f menggunakan bantuan program Statistical Package for the Social Sciences (SPSS). Hasil uji t penelitian ini menunjukan bahwa faktor budaya tidak berpengaruh terhadap keputusan nasabah dalam memilih Bank Syariah Mandiri Tajur Sedangkan faktor psikologis berpengaruh terhadap keputusan nasabah dalam memilih Bank Syariah Mandiri Tajur. Hasil uji F penelitian ini menunjukan faktor budaya dan psikologis berpengaruh nyata terhadap keputusan nasabah dalam memilih Bank Syariah Mandiri Tajur.

\section{Kata Kunci: Budaya, Psikologis, Keputusan Nasabah}

\section{PENDAHULUAN}

Bank Syariah merupakan salah satu aplikasi dari sistem ekonomi syariah Islam dalam mewujudkan nilai-nilai dan ajaran Islam yang mengatur bidang perekonomian umat yang tidak terpisahkan dari aspek-aspek ajaran Islam yang komprehensif dan universal. Komprehensif berarti ajaran Islam merangkum seluruh aspek kehidupan, baik ritual maupun sosial kemasyarakatan termasuk bidang ekonomi, universal bermakna bahwa syariah Islam dapat diterapkan dalam setiap waktu dan tempat tanpa memandang perbedaan ras, suku, golongan, dan agama sesuai prinsip Islam sebagai "rahmatan lil alamin". 
Bank syariah sebagai badan usaha dituntut mampu bersaing dengan lembaga keuangan lainnya untuk tetap bertahan hidup (survive). Salah satu cara yang harus ditempuh perusahaan dalam hal ini adalah dengan menentukan strategi yang tepat supaya tetap bertahan hidup di tengah persaingan serta dapat meningkatkan profitabilitasnya. Namun, dalam melakukan strateginya, perbankan akan mengalami suatu kegagalan apabila tidak didukung baik oleh pihak internal perbankan itu sendiri maupun pihak luar perbankan yang dalam hal ini diantaranya para nasabah.

Di Indonesia perbankan syariah memiliki potensi pasar yang sangat luas, diawali dengan keluarnya UU No. 7 tahun 1992 dan UU No. 10 tahun 1998 tentang perbankan syariah. Kesempatan ini dimanfaatkan oleh bank konvensional untuk mengkonversikan diri secara penuh manjadi bank umum syariah maupun membuka kantor umum bank syariah. Perbankan merupakan mediator atau lembaga intermediasi artinya kegiatan pengalihan atau penyaluran dana dari penabung (kelebihan dana) kepada peminjam (kekurangan dana).

Berdasarkan UU No. 21 Tahun 2008 Tentang Perbankan Syariah, bank syariah adalah bank yang menjalankan kegiatan usahanya berdasarkan prinsip syariah dan menurut jenisnya terdiri atas Bank Umum Syariah dan Bank Pembiayaan Rakyat Syariah. Adapun prinsip syariah yang dimaksud oleh UU tersebut adalah prinsip hukum islam dalam kegiatan perbankan berdasarkan fatwa yang dikeluarkan oleh lembaga yang memiliki kewenangan dalam penetapan fatwa di bidang syariah (Abdurrahman, 2006:18). Bank syariah merupakan bank yang dalam melaksanakan segala aktivitasnya berdasarkan dan berusaha sesuai dengan prinsip-prinsip syariah (Mufraini, 2009:12).

Berdasarkan pemaparan di atas dapat disimpulkan Bank syariah merupakan badan usaha yang menghimpun dana dari masyarakat dalam bentuk simpanan dan menyalurkannya kepada masyarakat dalam bentuk pembiayaan atau bentuk lainnya berdasarkan prinsip syariah dalam rangka meningkatkan taraf hidup orang banyak.

Pertumbuhan perbankan syariah menjadi menarik untuk diamati bila dikaitkan dengan tujuan awal berdirinya bank syariah. Sebagaimana dikatakan oleh M. syafi'i Antonio bahwa tujuan utama dari pendirian lembaga keuangan syariah ini adalah tiada lain sebagai upaya kaum muslimin untuk mendasari segenap aspek kehidupan ekonominya berlandaskan syariah islam (Antonio, 2001:18).

Dari sini terlihat adanya keterkaitan (hubungan) secara religius antara berdirinya bank syariah dengan tujuan untuk memfasilitasi mayoritas umat Islam dalam segenap aspek ekonominya, agar sesuai dengan syariat islam. Fenomena ini diperkuat pula dengan adanya fatwa yang dikeluarkan oleh komisi fatwa majelis ulama Indonesia (MUI) berkaitan dengan dilarangnya sistem bunga dalam segala praktik bisnis, termasuk bisnis industri perbankan. 
Salah satu faktor pendukung perkembangan perbankan syariah adalah minat masyarakat dalam memilih lembaga keuangan. Minat didefiniskan suatu model sikap seseorang terhadap obyek barang yang sangat cocok dalam mengukur sikap terhadap golongan produk, jasa atau merek tertentu (Schiffman, Kanuk, 2007:228).

Pembelian konsumen sangat dipengaruhi oleh karakteristik budaya, sosial, pribadi dan psikologis. Sebagian besar dari faktor-faktor tersebut tidak dapat dikendalikan oleh pemasar, namun mereka harus dapat mempertimbangkannya (Kotler, 2004:200). Selanjutnya, menurut Husein Umar, perilaku konsumen atau nasabah memang sangat menentukan dalam proses pengambilan keputusan pembelian atau pemilihan produk tertentu.

Faktor yang mempengaruhi pembelian konsumen secara eksternal salah satunya karekteristik budaya dan secara internal adalah psikologis. Kebudayaan sangat erat hubungannya dengan masyarakat oleh karena itu kebudayaan dapat mempengaruhi prilaku konsumen dalam memilih suatu produk tertentu, budaya terbentuk dari banyak unsur yang termasuk sistem agama dan politik, adat istiadat, bahasa, perkakas, pakaian, bangunan, dan karya seni. Dengan adanya pergeseran kebudayaan maka, perilaku konsumen mengalami perubahan. Dengan memahami beberapa bentuk budaya dari masyarakat dapat membantu pemasar dalam memprediksi penerimaan konsumen terhadap suatu produk. Pengaruh budaya dapat mempengaruhi masyarakat secara tidak sadar. Pengaruh budaya sangat alami dan otomatis sehingga pengaruhnya terhadap perilaku sering diterima begitu saja.

Faktor psikologis merupakan cara yang digunakan untuk mengenali perasaan mereka, mengumpulkan dan menganalisis informasi, merumuskan pikiran dan pendapat dalam mengambil tindakan, pilihan pembelian seseorang dipengaruhi oleh empat faktor psikologis utama, yaitu motivasi, persepsi, pengetahuan, keyakinan dan sikap. Psikologis merupakan satu faktor yang timbul dari dalam diri konsumen yang sangat mempengaruhi keputusan pembelian. menentukan bagaimana individu menerima dan berinteraksi dengan lingkungannya dan pengaruh pada keputusan yang diambil.

Dengan mengetahui alasan masyarakat memutuskan untuk menjadi nasabah bank, pihak bank akan mendapatkan gambaran mengenai bagaimana strategi pengembangan yang akan dilakukan untuk kemajuan bank ditengah persaingannya. Berdasarkan uraian tersebut, penulis ingin mengadakan penelitian mengenai perilaku konsumen dengan judul: "Pengaruh Faktor Budaya dan Psikologis terhadap Keputusan Nasabah Dalam Memilih Bank Syariah: Study Kasus pada Bank Syariah Mandiri Kcp Tajur"

Berdasarkan perumusan masalah diatas tujuan yang hendak dan ingin dicapai dalam penelitian ini yaitu:

1. Untuk menganalisis pengaruh faktor budaya terhadap keputusan nasabah dalam memilih bank syariah. 
Vol 2 No 1 (2019) 89-110 P-ISSN 2620-295 E-ISSN 2747-0490

DOI: $1047467 /$ elmal.v2i1.316

2. Untuk menganalisis pengaruh faktor psikologis terhadap keputusan nasabah dalam memilih bank syariah.

3. Untuk menganalisis pengaruh faktor budaya dan psikologis berpengaruh terhadap keputusan nasabah dalam memilih bank syariah?

\section{METODE PENELITIAN}

\section{Kerangka Berfikir}

Berdasarkan uraian teoritis maka dapat digambarkan suatu kerangka pemikiran yang menyatakan bahwa budaya dan psikologis merupakan faktor yang berpengaruh terhadap keputusan nasabah. Oleh karena itu kerangka pemikiran teori dari penelitian ini adalah sebagai berikut:

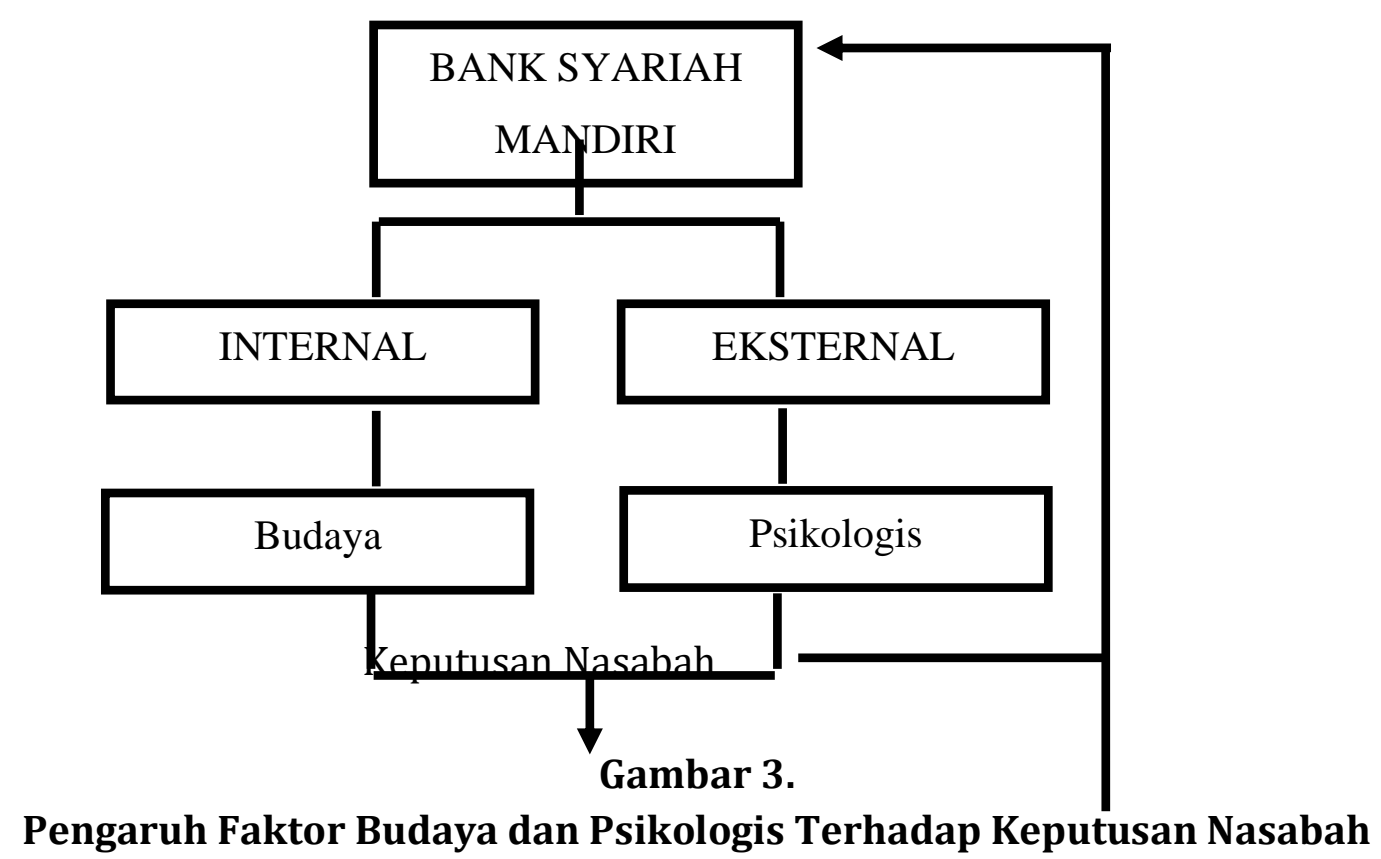

Dari kerangka pemikiran tersebut dapat dijelaskan bahwa terdapat dua variabel independen (bebas) yaitu budaya dan psikologis, serta variabel dependen (terikat) adalah keputusan nasabah.

Berdasarkan kerangka pemikiran tersebut, penelitian ini bertujuan menganalisis kedua variabel independen (bebas) tersebut mempunyai pengaruh nyata terhadap keputusan nasabah secara parsial maupun simultan, serta variabel independen manakah yang memberikan pengaruh nyata terhadap keputusan nasabah. 
Vol 2 No 1 (2019) 89-110 P-ISSN 2620-295 E-ISSN 2747-0490

DOI: $1047467 /$ elmal.v2i1.316

\section{Lokasi dan Waktu Penelitian}

Penelitian ini dilakukan di Bank Syariah Mandiri KCP Tajur Bogor, dengan waktu penelitian selama 2 bulan, mulai Februari 2017 sampai dengan maret 2017.

\section{Jenis Penelitian}

Jenis penelitian ini merupakan penelitian deskriptif kualitatif dengan metode survey yakni penelitian yang bertujuan dan menjelaskan suatu hal yang seperti apa adanya. Penelitian Survey adalah penelitian yang mengambil sampel dari suatu populasi dengan menggunakan kuesioner sebagai alat pengumpul data. Penelitian survey di sini bertujuan menjelaskan hubungan kausal dan pengujian hipotesis pengaruh budaya dan psikologis terhadap keputusan nasabah dalam memilih bank syraiah (Study Kasus pada Bank Syariah Mandiri KCP Tajur)

\section{Pengumpulan Data}

Untuk memperoleh data secara terperinci dan baik, penelitian ini menggunakan data primer yang diperoleh melalui kuesioner. Kuesioner adalah teknik pengumpulan data yang dilakukan dengan cara memberi seperangkat pertanyaan atau pernyataan tertulis kepada responden untuk dijawabnya (Sugiono, 2009:1999). Dalam penelitian ini peneliti menyebarkan kuesioner kepada nasabah Bank Mandiri Syariah KCP Tajur Bogor.

\section{Teknik Pengambilan Sampel}

Dalam penelitian ini, pengambilan sampel menggunakan pendekatan Tabachic \& Fidell. Pengambilan sampel dengan teknik Tabachic \& Fidell adalah jumlah variabel independen dikalikan dengan 10-25 (Ferdinand, 2006). Jumlah variabel independen dalam penelitian ini ada dua, sehingga jumlah sampel yang dibutuhkan berada pada kisaran 20-50. Oleh karena itu, jumlah sampel yang digunakan 100 sampel, karena apabila ukuran sampel yang diambil 50, jumlah sampel menjadi terlalu kecil sehingga diputuskan memilih 100 sampel sebagai jumlah sampel terbesar.

\section{Pengolahan dan Analisis Data Variabel Penelitian dan Definisi Operasional Variabel}

Variabel penelitian ini terdapat dua variabel, yaitu variable independen (bebas) dan variabel dependen (terikat). Variabel independen adalah variabel yang memengaruhi atau menyebabkan terjadinya perubahan pada variabel dependen (Maman dan Sambas, 2011:74). Dalam penelitian ini, variabel bebas adalah budaya $\left(\mathrm{X}_{1}\right)$ dan psikologis $\left(\mathrm{X}_{2}\right)$. Variabel dependen adalah variabel yang dipengaruhi atau yang menjadi 
akibat karena adanya variabel bebas (Maman dan Sambas, 2011:75). Dalam penelitian ini yang bertindak sebagai variabel terikat adalah keputusan nasabah (Y).

Tabel 1.

Definisi Oprasional Variabel

\begin{tabular}{|c|c|c|c|c|}
\hline No & Variabel & $\begin{array}{c}\text { Definisi } \\
\text { Operasional }\end{array}$ & Indikator & Pengukuran \\
\hline 1 & Budaya $\left(\mathrm{X}_{1}\right)$ & $\begin{array}{l}\text { Faktor budaya } \\
\text { mempunyai } \\
\text { pengaruh paling } \\
\text { luas dan } \\
\text { mendalam } \\
\text { terhadap perilaku } \\
\text { konsumen }\end{array}$ & $\begin{array}{l}\text { Kebudayaan } \\
\text { (kultur), } \\
\text { subkultur, kelas } \\
\text { social. }\end{array}$ & Skala Likert \\
\hline 2 & Psikologis $\left(\mathrm{X}_{2}\right)$ & $\begin{array}{l}\text { Merupakan cara } \\
\text { yang digunakan } \\
\text { untuk mengenali } \\
\text { perasaan mereka, } \\
\text { mengumpulkan } \\
\text { dan menganalisis } \\
\text { informasi, } \\
\text { merumuskan } \\
\text { pikiran dan } \\
\text { pendapat dan } \\
\text { mengambil } \\
\text { tindakan. }\end{array}$ & $\begin{array}{l}\text { Motivasi, } \\
\text { persepsi, } \\
\text { pengetahuan, } \\
\text { kepercayaan } \\
\text { dan sikap } \\
\text { pendirian. }\end{array}$ & Skala Likert \\
\hline 3 & $\begin{array}{l}\text { Keputusan } \\
\text { nasabah (Y) }\end{array}$ & $\begin{array}{l}\text { Ketertarikan } \\
\text { seseorang } \\
\text { terhadap suatu } \\
\text { jasa }\end{array}$ & $\begin{array}{l}\text { Ketertarikan, } \\
\text { perhatian dan } \\
\text { pencarian } \\
\text { informasi }\end{array}$ & Skala Likert \\
\hline
\end{tabular}

\section{HASIL DAN PEMBAHASAN}

\section{Gambaran Umum Bank Syariah Mandiri}

Krisis moneter dan ekonomi sejak Juli 1997, yang disusul dengan krisis politik nasional telah membawa dampak besar dalam perekonomian nasional. Krisis tersebut telah mengakibatkan perbankan Indonesia yang didominasi oleh bank-bank 
konvensional mengalami kesulitan yang sangat parah. Keadaan tersebut menyebabkan pemerintah Indonesia terpaksa mengambil tindakan untuk merestrukturisasi dan merekapitalisasi sebagian bank-bank di Indonesia. Lahirnya Undang-Undang No. 10 tahun 1998, tentang Perubahan atas Undang-Undang No. 7 tahun 1992 tentang Perbankan, pada bulan November 1998 telah memberi peluang yang sangat baik bagi tumbuhnya bank-bank syariah di Indonesia. Undang-Undang tersebut memungkinkan bank beroperasi sepenuhnya secara syariah atau dengan membuka cabang khusus syariah.

PT. Bank Susila Bakti (PT. Bank Susila Bakti) yang dimiliki oleh Yayasan Kesejahteraan Pegawai (YKP) PT. Bank Dagang Negara dan PT. Mahkota Prestasi berupaya keluar dari krisis 1997-1999 dengan berbagai cara. Mulai dari langkah-langkah menuju merger sampai pada akhirnya memilih konversi menjadi bank syariah dengan suntikan modal dari pemilik. Dengan terjadinya merger empat bank (Bank Dagang Negara, Bank Bumi Daya, Bank Exim dan Bapindo) ke dalam PT. Bank Mandiri (Persero) pada tanggal 31 Juli 1999, rencana perubahan PT. Bank Susila Bakti menjadi bank syariah (dengan nama Bank Syariah Sakinah) diambil alih oleh PT. Bank Mandiri (Persero).

PT. Bank Mandiri (Persero) selaku pemilik baru mendukung sepenuhnya dan melanjutkan rencana perubahan PT. Bank Susila Bakti menjadi bank syariah, sejalan dengan keinginan PT. Bank Mandiri (Persero) untuk membentuk unit syariah. Langkah awal dengan merubah Anggaran Dasar tentang nama PT. Bank Susila Bakti menjadi PT. Bank Syariah Sakinah berdasarkan Akta Notaris: Ny. Machrani M.S. SH, No. 29 pada tanggal 19 Mei 1999. Kemudian Sutjipto, SH nama PT. Bank Sya i No. 23 tanggal 8 September 1999 Notaris: Mandiri.

Pada tanggal 25 Oktober 1999, Bank Indonesia melalui Surat Keputusan Gubernur Bank Indonesia No. 1/24/KEP.BI/1999 telah memberikan ijin perubahan kegiatan usaha konvensional menjadi kegiatan usaha berdasarkan prinsip syariah kepada PT. Bank Susila Bakti. Selanjutnya dengan Surat Keputusan Deputi Gubernur Senior Bank Indonesia No. 1/1/KEP.DGS/1999 tanggal 25 Oktober 1999, Bank Indonesia telah menyetujui perubahaan nama PT. Bank Susila Bakti menjadi PT. Bank Syariah Mandiri. Senin tanggal 25 Rajab 1420 H atau tanggal 1 November 1999 merupakan hari pertama beroperasinya PT. Bank Syariah Mandiri. Kelahiran Bank Syariah Mandiri merupakan buah usaha bersama dari para perintis bank syariah di PT. Bank Susila Bakti dan Manajemen PT. Bank Mandiri yang memandang pentingnya kehadiran bank syariah di lingkungan PT. Bank Mandiri (Persero).

PT. Bank Syariah Mandiri hadir sebagai bank yang mengkombinasikan idealisme usaha dengan nilai-nilai rohani yang melandasi operasinya. Harmoni antara idealisme usaha dan nilai-nilai rohani inilah yang menjadi salah satu keunggulan PT. Bank Syariah 
Mandiri sebagai alternatif jasa perbankan di Indonesia. Sebagai bank syariah terbesar dengan jaringan terluas di Tanah Air, Bank Syariah Mandiri memiliki 169 outlet yang tersebar di 23 provinsi di Indonesia. Bank Syariah Mandiri memiliki layanan perbankan yang real time dan online di semua outlet.

\section{Deskripsi Penelitian}

\section{Karakteristik Responden}

Penelitian mengenai pengaruh budaya dan psikologis terhadap keputusan nasabah dalam memilih bank syariah pada Bank Syariah Mandiri KCP Tajur menggunakan responden sebanyak 100 orang nasabah Bank Syariah Mandiri KCP Tajur. Terdapat lima karakteristik responden yang dimasukan dalam penelitian, yaitu berdasarkan jenis kelamin, status, usia, pendidikan dan pekerjaan.

Jenis kelamin responden terdiri dari 54\% laki-laki dan 46\% perempuan. Sekitar $70 \%$ di antara mereka berstatus telah menikah. Usia mereka 68\% pada rentang 25-45 tahun, 18\% di bawah 25 tahun, dan $14 \%$ di atas 45 tahun. Sementara berdasarkan pekerjaannya, 61\% bekerja di sektor swasta, 10\% PNS, 8\% pelajar dan mahasiswa. Lainnya 20\% bekerja tidak tetap. Dari segi Pendidikan, 40\% SLTA, 38\% sarjana, 9\% SMP, $5 \%$ SD, dan $8 \%$ pascasarjana.

\section{Analisis Penelitian}

\section{Uji Validitas dan Reliabilitas}

Dalam penelitian ini dilakukan terlebih dahulu uji validitas per item pertanyaan sebelum dilakukan analisis lebih lanjut. Uji validitas dan reliabilitas dilakukan dengan menggunakan software IBM SPSS Statistics 21. Dalam uji validitas dan reliabilitas peneliti menggunakan jumlah sampel sebanyak 100 responden. Berikut adalah tabel uji validitas dan reliabilitas.

Hasil Uji Validitas dan Reliabilitas terhadap Budaya $\left(\mathrm{X}_{1}\right)$ / Hasil uji validitas untuk variabel budaya dapat dilihat pada tabel 4.6 di bawah ini:

Tabel 7. Tabel Validitas pada Budaya $\left(\mathrm{X}_{1}\right)$

\begin{tabular}{|c|r|r|c|}
\hline Indikator & $\begin{array}{c}\text { CorrectedItem- } \\
\text { Total } \\
\text { Correlation }\end{array}$ & $\mathrm{r}$ table & Keterangan \\
\hline P1 &, 291 &, 196 & Valid \\
\hline P2 &, 419 &, 196 & Valid \\
\hline P3 &, 539 &, 196 & Valid \\
\hline
\end{tabular}


Vol 2 No 1 (2019) 89-110 P-ISSN 2620-295 E-ISSN 2747-0490

DOI: $1047467 /$ elmal.v2i1.316

\begin{tabular}{|l|r|r|l|} 
P4 &, 485 &, 196 & Valid \\
\hline P5 &, 346 &, 196 & Valid \\
\hline P6 &, 380 &, 196 & Valid \\
\hline P7 &, 564 &, 196 & Valid \\
\hline
\end{tabular}

Sumber: Peneliti, Output IBM SPSS Statistics 21 yang diolah,2017

Hasil pengujian validitas item kuesioner menunjukan bahwa seluruh item pernyataan dalam setiap variabel budaya memiliki nilai $r_{\text {hitung }}$ lebih besar dari $r_{\text {tabel }}$, maka dapat disimpulkan seluruh item angket variabel budaya valid dan dapat digunakan untuk mengukur variabel yang diteliti.

Selanjutnya, untuk menguji reliabilitas dari instrumen penelitian dikatakan reliabel jika nilai $\alpha \geq 0.6$ (Nunnally dalam Imam Ghozali 2013;48), sehingga data dapat digunakan sebagai bahan penelitian untuk analisis data. Berdasarkan hasil pengolahan data pada software SPSS 21 hasil pengujian reliabilitas yang diperoleh tabel 4.7 di bawah ini:

Tabel 8. Hasil Uji Realibilitas pada Budaya $\left(\mathrm{X}_{1}\right)$

\begin{tabular}{|l|l|l|l|}
\hline Indikator & $\begin{array}{l}\text { Correctedltem- } \\
\text { Total Correlation }\end{array}$ & $\mathrm{r}_{\text {table }}$ & Keterangan \\
\hline P8 &, 516 &, 196 & Valid \\
\hline P9 &, 618 &, 196 & Valid \\
\hline P10 &, 474 &, 196 & Valid \\
\hline P11 &, 613 &, 196 & Valid \\
\hline P12 &, 601 &, 196 & Valid \\
\hline
\end{tabular}

Sumber: Output IBM SPSS Statistics 21 yang diolah,2017

Berdasarkan hasil perhitungan di atas, dapat dikatakan bawa instrumen penelitian menunjukan reliabel, karena nilai Alpha Cronbach's $0.804 \geq 0,6$. Jadi instrumen penelitian dinyatakan dapat digunakan.

Hasil Uji Validitas dan Reliabilitas pada Psikologis $\left(\mathrm{X}_{2}\right)$. Hasil uji validitas untuk variabel psikologis dapat dilihat pada tabel 4.8 di bawah ini:

Tabel 9. Tabel Validitas pada Psikologis $\left(\mathrm{X}_{2}\right)$

\begin{tabular}{|l|l|l|}
\hline Cronbach's Alpha & $\begin{array}{l}\text { Cronbach's Alpha Based } \\
\text { on Standardized Items }\end{array}$ & of Items \\
\hline .761 & .804 & 8 \\
\hline & & \\
\hline
\end{tabular}

Sumber: Peneliti, Output IBM SPSS Statistics 21 yang di olah, 2017 
Hasil pengujian validitas item kuesioner menunjukan bahwa seluruh item pernyataan dalam setiap variabel psikologis memiliki nilai $r_{\text {hitung }}$ lebih besar dari $r_{\text {tabel }}$, maka dapat disimpulkan seluruh item angket variabel psikologis valid dan dapat digunakan untuk mengukur variabel yang diteliti.

Selanjutnya, untuk menguji reliabilitas dari instrumen penelitian dikatakan reliabel jika nilai $\alpha \geq 0.6$ (Nunnally dalam Imam Ghozali 2013:48), sehingga data dapat digunakan sebagai bahan penelitian untuk analisis data. Berdasarkan hasil pengolahan data pada software SPSS 21 hasil pengujian reliabilitas yang diperoleh tabel 4.9 di bawah ini:

Tabel 10. Hasil Uji Reliabel pada Psikologis $\left(X_{2}\right)$

\begin{tabular}{|l|l|l|}
\hline Cronbach's Alpha & $\begin{array}{l}\text { Cronbach's Alpha Based } \\
\text { on Standardized Items }\end{array}$ & \\
& & \\
\hline 830 & .854 & 6 \\
\hline
\end{tabular}

Sumber: Peneliti, Output IBM SPSS Statistics 21 yang di olah, 2017

Berdasarkan hasil perhitungan di atas, dapat dikatakan bawa instrumen penelitian menunjukan reliabel, karena nilai Alpha Cronbach's $0.854 \geq 0,6$. Jadi instrumen penelitian dinyatakan dapat digunakan.

Hasil Uji Validitas dan Reliabilitas pada Keputusan Nasabah (Y)

Tabel 11. Tabel Validitas pada Keputusan Nasabah

\begin{tabular}{|c|c|c|c|}
\hline Indikator & $\begin{array}{c}\text { Corrected Item- } \\
\text { Total } \\
\text { Correlation }\end{array}$ & $\mathrm{r}$ table & Keterangan \\
\hline P13 &, 649 &, 196 & Valid \\
\hline P14 &, 562 &, 196 & Valid \\
\hline P15 &, 624 &, 196 & Valid \\
\hline P16 &, 684 &, 196 & Valid \\
\hline P17 &, 620 &, 196 & Valid \\
\hline P18 &, 505 &, 196 & Valid \\
\hline
\end{tabular}

Sumber: Peneliti, OutputIBM SPSS Statistics 21 yang di olah, 2017

Uji validitas data pada penelitian ini dengan membandingkan nilai $r_{h i t u n g}$ dengan $r_{\text {tabel }}$ pada taraf kepercayaan 95\% atau signifiansi 5\% $(\alpha=0,05)$ dapat dicari berdasarkan jumlah responden atau N. Karena $N=100$, maka derajat bebasnya adalah $\mathrm{N}-2=100-2=$ 
98. Nilai $r$ tabel pada $\mathrm{df}=98$ dan $\alpha=0,05$ adalah 0,196 . Dari hasil analisis diperoleh $\mathrm{r}$ hitung pada variabel keputusan nasabah $\geq \mathrm{r}$ table, maka item pertanyaan tersebut dikatakan valid.

Selanjutnya, untuk menguji reliabilitas dari instrumen penelitian dikatakan reliabel jika nilai $\alpha \geq 0.6$ (Nunnally:2013), sehingga data dapat digunakan sebagai bahan penelitian untuk analisis data. Berdasarkan hasil pengolahan data pada software SPSS 21 hasil pengujian reliabilitas yang diperoleh tabel 4.11 di bawah ini:

\section{Tabel 12. Hasil Uji Reliabilitas pada Keputusan Nasabah}

\begin{tabular}{|r|r|r|}
\hline Cronbach's Alpha & $\begin{array}{c}\text { Cronbach's Alpha } \\
\text { Based on } \\
\text { Standardized Items }\end{array}$ & N of Items \\
\hline .864 & .882 & 7 \\
\hline
\end{tabular}

Sumber: Output IBM SPSS Statistics 21 yang diolah, 2017

Berdasarkan hasil perhitungan di atas, dapat dikatakan bawa instrumen penelitian menunjukan reliable, karena nilai Alpha Cronbach's $0.882 \geq 0,6$. Jadi instrumen penelitian dinyatakan dapat digunakan.

\section{Uji Asumsi Klasik}

Sebelum dilakukan pengujian hipotesis menggunakan regresi linier berganda, ada beberapa uji asumsi klasik yang harus dipenuhi agar kesimpulan dari regresi tersebut tidak bias, yaitu uji heteroskedastisitas, uji normalitas, uji multikolonieritas, uji autokorelasi.

\section{Uji Heteroskedastisitas}

Uji heteroskedastisitas dilakukan untuk menguji apakah dalam suatu model regresi terjadi perbedaan variance dari residual data yang ada. Dalam penelitian ini uji heteroskedastisitas dilakukan dengan analisa grafik plot antara nilai prediksi variabel terikat (ZPRED) dengan residualnya (SRESID). Pengujian ini menggunakan SPSS 21 dengan hasil sebagai berikut:

Scatterplot

Dependent Variable: KEPUTUSAN

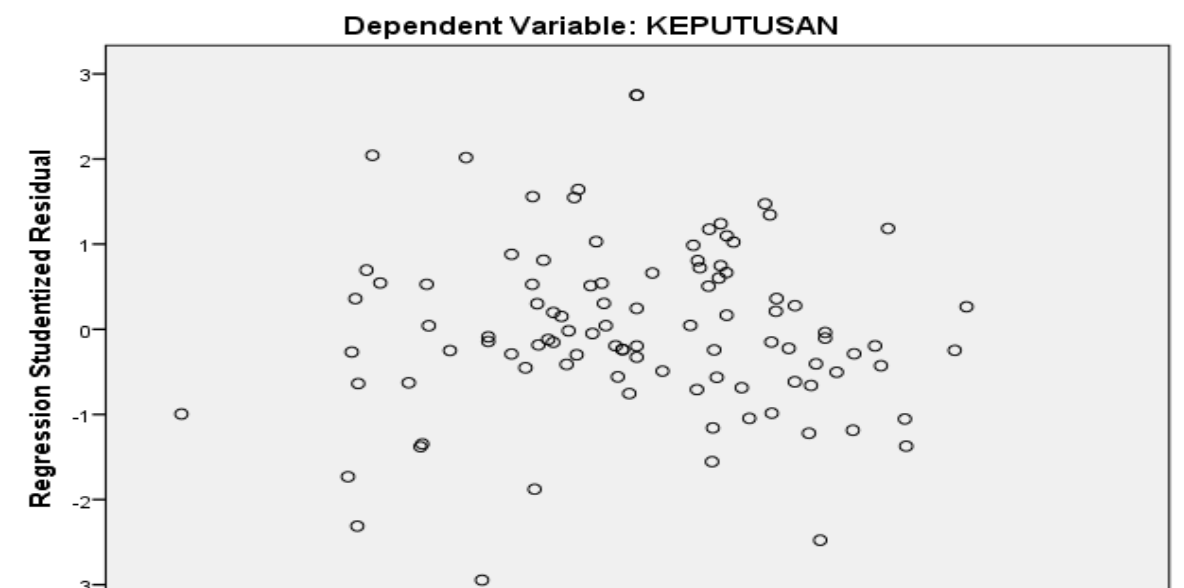


Sumber: Output IBM SPSS Statistics 21 yang di olah, 2017

\section{Gambar 4.}

\section{Uji Heteroskedastisitas}

Dasar analisa uji heteroskedastisitas dengan grafik plot adalah jika titik dalam grafik tersebut tidak membentuk pola maka tidak terjadi heteroskedastisitas. Berdasarkan gambar tersebut dapat dilihat bahwa titik-titik yang ada tidak membentuk pola yang teratur. Sehingga dapat disimpulkan bahwa pada data dalam penelitian ini tidak terjadi heteroskedastisitas. Artinya dalam fungsi regresi di penelitian ini tidak muncul gangguan karena varian yang tidak sama.

\section{Hasil Uji Normalitas}

Uji normalitas dilakukan untuk mengetahui apakah data yang diambil dalam penelitian berasal dari populasi yang berdistribusi normal atau tidak. Alat analisis yang digunakan untuk menguji normalitas data adalah dengan uji Kolmogorov-Smirnov. Sampel berdistribusi normal apabila asymptotic sig $>0,05$, sebaliknya dikatakan tidak normal apabila asymptotic sig < 0,05. Pengujian ini menggunakan program SPSS versi 21 .

\section{Tabel 14. Uji Normalitas}

\section{One-Sample Kolmogorov-Smirnov Test}

\begin{tabular}{|c|c|c|c|c|}
\hline & & budaya & $\begin{array}{c}\text { psikologi } \\
\text { s }\end{array}$ & $\begin{array}{c}\text { keputusa } \\
\mathrm{n}\end{array}$ \\
\hline \multicolumn{2}{|l|}{$\mathrm{N}$} & 100 & 100 & 100 \\
\hline \multirow{3}{*}{$\begin{array}{l}\text { Normal } \\
\text { Parameters }{ }^{\mathrm{a}, \mathrm{b}}\end{array}$} & Mean & 3.1876 & 3.3072 & 3.4496 \\
\hline & Std. & .54479 & .63170 & .63623 \\
\hline & Deviation & & & \\
\hline \multirow{3}{*}{$\begin{array}{l}\text { Most } \quad \text { Extreme } \\
\text { Differences }\end{array}$} & Absolute & .061 & .083 & .097 \\
\hline & Positive & .061 & .067 & .063 \\
\hline & Negative & -.058 & -.083 & -.097 \\
\hline \multicolumn{2}{|l|}{ Kolmogorov-Smirnov Z } & 609 & .832 & .971 \\
\hline \multicolumn{2}{|l|}{ Asymp. Sig. (2-tailed) } & .853 & .493 & .303 \\
\hline
\end{tabular}

a. Test distribution is Normal.

b. Calculated from data.

Sumber: Output IBM SPSS Statistics 21 yang di olah, 2017

Berdasarkan hasil perhitungan diperoleh asymptod signifikasi variabel budaya $0.853 \geq 0.05$ maka data dari variabel budaya berdistribusi normal. Sedangkan untuk 
asymptod signifikasi variabel psikologis $0.493 \geq 0.05$ maka data dari variabel psikologis berdistribusi normal. Dan untuk asymptod signifikasi variabel keputusan $0.303 \geq 0.05$ maka data dari variabel keputusan berdistribusi normal.

\section{Uji Multikolinieritas}

Uji multikolinieritas bertujuan untuk menguji ada tidaknya korelasi antara variabel independent (bebas) dan variabel dependent (terikat) dalam suatu model regresi. Uji multikolinieritas penelitian ini dilakukan dengan melihat nilai variance inflation facto (VIF) dengan menggunakan SPSS 21 dan diperoleh hasil sebagai berikut:

\section{Tabel 15. Hasil Uji Multikolonieritas}

\begin{tabular}{|l|r|r|c|}
\hline Variabel & Tolerance & VIF & Keterangan \\
\hline Budaya & 0.646 & 1.549 & $\begin{array}{c}\text { Tidak terjadi } \\
\text { multikolonieritas }\end{array}$ \\
\hline Psikologis & 0.646 & 1.549 & $\begin{array}{c}\text { Tidak terjadi } \\
\text { multikolonieritas }\end{array}$ \\
\hline
\end{tabular}

Sumber: Peneliti, Output IBM SPSS Statistics 21 yang di olah,2017

Sesuai dengan ketentuan uji multikolinieritas, jika nilai VIF $\leq 10$ dan nilai tolerance $\geq 0.10$ maka tidak terdapat korelasi. Berdasarkan tabel diatas dapat dilihat bahwa nilai VIF yaitu $1.549 \leq 10$ dan nilai tolerance $\geq 0.10$ sehingga dapat disimpulkan bahwa tidak terdapat multikolinieritas dalam data penelitian ini. Artinya bahwa antara variabel budaya dan psikologis tidak saling mengganggu atau mempengaruhi.

\section{Uji Autokolerasi}

Autokorelasi pada model regresi artinya ada korelasi antar anggota sampel yang diurutkan berdasarkan waktu saling berkorelasi. Untuk mengetahui adanya autokorelasi dalam suatu model regresi dilakukan melalui pengujian terhadap nilai uji Durbin Watson (Uji DW) dengan ketentuan sebagai berikut (Algifari, 2000) :

$\begin{array}{ll}\text { DL } & =1,4797 \\ \text { DU } & =1,6889 \\ \text { Kurang 1,4797 } & =\text { Ada autokorelasi } \\ 1,4797 \mathrm{~s} / \mathrm{d} 1,6889 & =\text { Tanpa kesimpulan } \\ 1,6889 \mathrm{~s} / \mathrm{d} \mathrm{2,3111} & =\text { Tidak ada autokorelasi } \\ 2,3111 \mathrm{~s} / \mathrm{d} \mathrm{3,213} & =\text { Tanpa kesimpulan } \\ \text { Lebih dari 3,213 } & =\text { Ada autokorelasi }\end{array}$


Vol 2 No 1 (2019) 89-110 P-ISSN 2620-295 E-ISSN 2747-0490

DOI: $1047467 /$ elmal.v2i1.316

\section{Tabel 16. Hasil Uji Autokorelasi DW}

Model Summaryb

\begin{tabular}{|l|r|r|r|}
\hline \multirow{2}{*}{ Model } & \multicolumn{2}{|c|}{ Change Statistics } & \multirow{2}{*}{ Durbin-Watson } \\
\cline { 2 - 3 } & df2 & Sig. F Change & \\
\hline 1 & $97 \mathrm{a}$ & .000 & 1.967 \\
\hline
\end{tabular}

Sumber: Output IBM SPSS Statistics 21 yang di olah,2017

Dari hasil data di atas dapat dijelaskan model nilai DW sebesar 1.967 Jadi, dapat disimpulkan bahwa tidak ada autokorelasi pada model regresi.

\section{Uji Hipotesis}

\section{Uji Koefisien Determinan}

Untuk mengetahui hubungan antara dua atau lebih variabel independent dengan satu variabel dependent (budaya dan psikologis terhadap keputusan nasabah), akan dihitung menggunakan software IBM SPSS Statistics 21 sebagai berikut:

Tabel 17. Hasil Uji Koefisien Determinan

\begin{tabular}{|c|c|c|c|c|c|c|c|}
\hline \multirow{2}{*}{$\begin{array}{l}\text { Mo } \\
\text { del }\end{array}$} & \multirow[t]{2}{*}{$\mathrm{R}$} & \multirow{2}{*}{$\begin{array}{c}\mathrm{R} \\
\text { Squar } \\
\mathrm{e}\end{array}$} & \multirow{2}{*}{$\begin{array}{l}\text { Adjusted } \\
\text { R Square }\end{array}$} & \multirow{2}{*}{$\begin{array}{c}\text { Std. } \\
\text { Error of } \\
\text { the } \\
\text { Estimate }\end{array}$} & \multicolumn{3}{|c|}{ Change Statistics } \\
\hline & & & & & $\begin{array}{l}\text { R Square } \\
\text { Change }\end{array}$ & $\begin{array}{c}\text { F } \\
\text { Chang } \\
\text { e }\end{array}$ & df1 \\
\hline 1 & $.710^{\mathrm{a}}$ & .505 & .494 & .45242 & .505 & $\begin{array}{r}49.39 \\
2\end{array}$ & 2 \\
\hline
\end{tabular}

Sumber: Peneliti, Output IBM SPSS Statistics 21 yang di olah, 2017

Besarnya $\mathrm{R}$ square $\left(\mathrm{R}^{2}\right)$ pada tabel di atas adalah 0,505. Angka tersebut mempunyai makna besarnya pengaruh variabel budaya dan psikologis terhadap kepuasan nasabah secara gabungan. Angka 50,5\% merupakan besarnya pengaruh variabel budaya dan psikologis secara gabungan. Sedangkan sisanya 49,5\% s mempunyai makna besarnya faktor lain diluar kedua variabel diatas yang tidak diteliti.

\section{Pengujian Signifikasi Parameter Individual (Uji t)}

Uji t dilakukan untuk mengetahui pengaruh masing-masing variabel bebas yang terdiri dari budaya dan psikologis tarhadap variabel terikat keputusan nasabah dengan membandingkan nilai $t$ hitung pada taraf signifikan 0,00 dengan $t$ tabel dengan taraf signifikan 0,05 dan DK (Derajat Kebebasan) dengan rumus $\mathrm{n}-\mathrm{k}$. Dimana $\mathrm{n}=$ banyak 
observasi sedangkan $\mathrm{k}$ = banyaknya variabel (bebas dan terikat). Untuk pengujian hipotesis $t$ kriterianya sebagai berikut :

Jika t hitung $\geq \mathrm{t}$ tabel, maka $\mathrm{H}_{\mathrm{o}}$ ditolak dan $\mathrm{H}_{\mathrm{a}}$ diterima

Jika t hitung $\leq \mathrm{t}$ tabel, maka $\mathrm{H}_{\mathrm{o}}$ diterima dan $\mathrm{H}_{\mathrm{a}}$ ditolak

Dapat dituntjukkan pada tabel 4.16 sebagai berikut:

Tabel 18.

Hasil Uji Regresi Liniear Berganda dan Uji Statistik t

Coefficients $^{\mathrm{a}}$

\begin{tabular}{|c|c|c|c|c|c|c|c|}
\hline \multirow{2}{*}{\multicolumn{2}{|c|}{ Model }} & \multicolumn{2}{|c|}{$\begin{array}{l}\text { Unstandardized } \\
\text { Coefficients }\end{array}$} & \multirow{2}{*}{$\begin{array}{l}\text { Standardized } \\
\text { Coefficients } \\
\text { Beta }\end{array}$} & \multirow[t]{2}{*}{$\mathrm{T}$} & \multirow[t]{2}{*}{ Sig. } & \multirow{2}{*}{\begin{tabular}{|l} 
Correl \\
ations \\
Zero- \\
order
\end{tabular}} \\
\hline & & $B$ & Std. Error & & & & \\
\hline \multirow{3}{*}{1} & (Constant) & .834 & .288 & & 2.900 & .005 & \\
\hline & BUDAYA & .197 & .104 & .169 & 1.895 & .061 & .524 \\
\hline & PSIKOLOGIS & .601 & .090 & .597 & 6.713 & .000 & .697 \\
\hline
\end{tabular}

Sumber: Peneliti, Output IBM SPSS Statistics 21 yang di olah,2017

Dari hasil uji parsial pada tabel 4.16, pengaruh masing-masing variabel bebas budaya dan psikologis terhadap variabel terikat keputusan nasabah dapat dijelaskan sebagai berikut:

Variabel Budaya $\left(\mathrm{X}_{1}\right)$

Nilai thitung untuk variabel ini sebesar 1,895 dengan nilai tabel dengan uji dua arah dan $\alpha=5 \%(0,05)$ sebesar 1,98447. Hasil uji tersebut menunjukkan nilai thitung $1,895<$ $t_{\text {tabel }}$ 1,98447. Sehingga dapat disimpulkan bahwa variabel budaya secara parsial atau terpisah tidak berpengaruh dan nilai taraf signifikan untuk variabel budaya sebesar 0,061 atau lebih besar dari 0,05 dengan demikian keputusannya adalah $\mathrm{H}_{\mathrm{o}}$ diterima dan $\mathrm{H}_{\mathrm{a}}$ ditolak. Artinya tidak ada pengaruh budaya terhadap kepuasan nasabah.

Variabel Psikologis $\left(\mathrm{X}_{2}\right)$

Nilai thitung untuk variabel ini sebesar 6,713 dengan nilai tabel dengan uji dua arah dan $\alpha=5 \%(0,05)$ sebesar 1,98447 . Hasil uji tersebut menunjukkan dan nilai thitung 6.713 $>$ tabel 1,98447. Sehingga dapat disimpulkan bahwa variabel psikologis secara parsial atau terpisah berpengaruh dan nilai taraf signifikan untuk variabel psikologis sebesar 0,000 atau lebih kecil dari 0,05 dengan demikian keputusannya adalah $\mathrm{H}_{\mathrm{o}}$ ditolak dan $\mathrm{H}_{\mathrm{a}}$ diterima. Artinya ada pengaruh psikologis terhadap kepuasan nasabah.

Berdasarkan uji t yang telah dilakukan maka dapat disimpulkan bahwa dari kedua variabel independen yang terdiri dari budaya dan psikologis, Variabel yang dapat mempengaruhi keputusan nasabah adalah variabel psikologis.

Hal ini dapat di lihat bahwa thitung $6.713>$ tabel 1,98447 sehingga dapat disimpulkan bahwa variabel psikologis secara parsial atau terpisah berpengaruh signifikan terhadap variabel keputusan nasabah. 
Vol 2 No 1 (2019) 89-110 P-ISSN 2620-295 E-ISSN 2747-0490

DOI: $1047467 /$ elmal.v2i1.316

\section{Uji Simultan (uji statistik f)}

Uji F pada dasarnya menunjukkan apakah semua variabel bebas yang dimasukkan dalam model mempunyai pengaruh secara simultan terhadap variabel terikat. Dalam penelitian ini pengujian hipotesis secara simultan dimaksudkan untuk mengukur besarnya pengaruh variabel bebas (budaya dan psikologis) terhadap variabel terikat (keputusan nasabah). Hasil uji F melalui software IBM SPSS Statistics 21 dapat dilihat pada tabel 4.17 di berikut ini:

\section{Tabel 19. Hasil Uji Statistik f}

\begin{tabular}{|c|c|c|c|c|c|c|}
\hline \multicolumn{7}{|c|}{ ANOVA $^{a}$} \\
\hline & & $\begin{array}{l}\text { Sum of } \\
\text { Squares }\end{array}$ & Df & $\begin{array}{c}\text { Mean } \\
\text { Square }\end{array}$ & $\mathrm{F}$ & Sig. \\
\hline \multirow{3}{*}{1} & Regression & 20.220 & 2 & 10.110 & 49.392 & $.000^{\mathrm{b}}$ \\
\hline & Residual & 19.855 & 97 & .205 & & \\
\hline & Total & 40.074 & 99 & & & \\
\hline
\end{tabular}

Sumber: Output IBM SPSS Statistics 21 yang diolah,2017

Berdasarkan tabel 4.17 diatas, maka dapat dilihat bahwa $F_{\text {hitung }}$ sebesar 49,392, sedangkan nilai $F_{\text {tabel }}$ distribusi dengan tingkat kesalahan 0,05 adalah sebesar 3,09. Hal ini berarti $F_{\text {hitung }}>F_{\text {tabel }}(49,392>3,09)$. Perhitungan tersebut menunjukkan bahwa variabel bebas yang terdiri dari budaya dan psikologis secara simultan berpengaru terhadap variabel terikat keputusan nasabah. Dengan demikian $\mathrm{H}_{\mathrm{o}}$ ditolak dan $\mathrm{H}_{\mathrm{a}}$ diterima. Artinya ada hubungan linear antara variabel budaya dan psikologis dengan kepuasan nasabah

\section{Perumusan Model Persamaan Regresi}

Hasil pengujian asumsi klasik yang telah dilakukan, dapat disimpulkan bahwa model regresi dalam penelitian ini layak digunakan. Selanjutnya dapat dilakukan uji estimasi linier berganda dan diinterpretasikan. Berdasarkan output regresi linier pada tabel $4.16 \mathrm{di}$ atas model regresi berganda yang digunakan dalam penelitian ini dapat dirumuskan sebagai berikut:

$$
\hat{Y}=0,834+0,197 \text { budaya }+0,601 \text { psikologis }+e
$$

Interpretasi dari analisis regresi:

- Konstanta $(\alpha)=0,834$ artinya apabila variabel budaya dan psikologis bernilai 0 , maka nilai keputusan nasabah dalam memilih bank syariah adalah 0,834 .

- Budaya $=0,197$ merupakan nilai koefisien regresi variabel budaya terhadap variabel keputusan nasabah artinya jika budaya mengalami kenaikan satu satuan, maka nilai keputusan nasabah naik sebesar 0,197. 
koefisien bernilai positif artinya antara budaya dan keputusan nasabah memiliki hubungan positif, Peningkatan budaya akan mengakibatkan peningkatan pada keputusan nasabah.

- Psikologis = 0,601 merupakan nilai koefisien regresi variabel psikologis terhadap variabel keputusan nasabah artinya jika psikologis mengalami kenaikan satu satuan, maka nilai keputusan nasabah naik sebesar 0,601. koefisien bernilai positif artinya antara psikologis dan keputusan nasabah memiliki hubungan positif, Peningkatan psikologis akan mengakibatkan peningkatan pada keputusan nasabah.

\section{Interpretasi Data}

Analisa regresi atas data mengahasilkan model sebagai berikut:

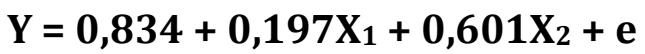

$\mathrm{Y} \quad=$ Keputusan nasabah

$\mathrm{X}_{1} \quad=$ Budaya

$\mathrm{X}_{2}=$ Psikologis

Interpretasi dan pembahasan model yang diperoleh dalam analisis regresi adalah sebagai berikut:

Nilai R square $\left(\mathrm{R}^{2}\right)$ 0,505 atau 50,5\% yang merupakan besarnya pengaruh variabel budaya dan psikologis secara gabungan. Hal ini menunjukan secara gabungan variabel budaya dan psikologis berpengaruh dominan terhadap keputusan nasabah dengan pengaruh secara langsung sebesar 50,5\% dan sisanya 49,5\% dipengaruhi oleh variabel lain lain yang tidak dijelaskan dalam penelitian ini. Untuk menguji apakah parameter koefisien R Square signifikan atau tidak ditunjukan dengan hasil pada tabel anova atau f test menunjukkan bahwa nilai F hitung sebesar 49,392 lebih besar dari F tabel sebesar 3,09 , dengan signifikansi sebesar $0,00<0,05$, maka budaya dan psikologis secara bersama-sama berpengaruh cukup kuat terhadap kepuasan nasabah.

Faktor-faktor yang memengaruhi perilaku konsumen ada empat faktor, yaitu faktor budaya, faktor sosial, faktor pribadi dan faktor psikologis (Sunyoto, Fathonah, 2015:132).

Dari hasil uji F, diperoleh nilai Fhitung 49,392 dengan sig 0,000 ini menjelaskan bahwa semua variabel independen (budaya dan psikologis) secara simultan dapat mempengaruhi keputusan nasabah dalam memilih bank syariah. Hal ini sesuai dengan penelitian yang dilakukan Rafif Mandana (2015) yaitu "Pengaruh Pribadi, Sosial, Kebudayaan Dan Psikologis Dalam Pengambilan Keputusan Nasabah Memilih Produk Perbankan Syariah", penelitian ini menggunakan dua variabel independen yang sama yaitu budaya dan psikologis, dimana uji F yang dilakukan Rafif Mandana (2015) budaya dan psikologis secara bersama-sama berpengaruh terhadap keputusan nasabah. 


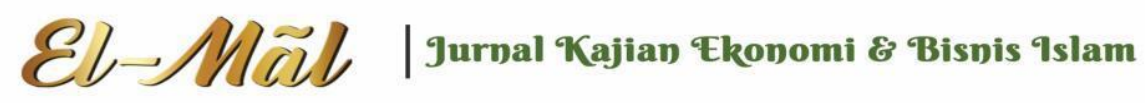

Vol 2 No 1 (2019) 89-110 P-ISSN 2620-295 E-ISSN 2747-0490

DOI: $1047467 /$ elmal.v2i1.316

\section{Uji t}

Hasil uji t pada variabel budaya tidak berpengaruh nyata terhadap keputusan nasabah dalam memilih bank syariah sebab nilai thitung 1,895 $\leq \mathbf{t}_{\text {tabel }} \mathbf{1 , 9 8 4 4 7}$ dan nilai sig $\geq \alpha$ yaitu $0,061 \geq 0,05$. Artinya $\mathrm{H}_{\mathrm{a}}$ ditolak dan $\mathrm{H}_{\mathrm{o}}$ diterima. Hasil penelitian ini sesuai dengan penelitian Atin Yulaifah (2001) yaitu "Pengaruh Budaya, Social, Pribadi dan Psikologis Terhadap Keputusan Nasabah Dalam Memilih Bank Syariah" dimana dari hasil penelitian di peroleh nilai $t_{\text {hitung }} \leq \mathbf{t}_{\text {tabel }}$ yaitu $1,673 \leq 1,985$ dan nilai sig $\geq \alpha$ yaitu 0,098 $\geq 0,05$.

Penelitian ini sejalan dengan teori (anwar prabu mangkunegara, 2005:39) kebudayaan merupakan suatu hal yang kompleks yang meliputi ilmu pengetahuan, kepercayaan, seni, moral, adat, kebiasaan, dan norma-norma yang berlaku pada masyarakat.

Budaya merupakan hasil kreativitas manusia dari satu generasi ke generasi berikutnya yang sangat menentukan bentuk prilaku dalam kehidupannya sebagai anggota masyarakat, jadi sangat mungkin ada pergeseran budaya yang menyebabkan terjadinya perubahan keputusan.

Hasil uji t pada variabel psikologis berpengaruh nyata terhadap keputusan nasabah dalam memilih bank syariah sebab nilai thitung $6,713 \geq \mathbf{t}_{\text {tabel }} \mathbf{1 , 9 8 4 4 7}$. Artinya $\mathrm{H}_{\mathrm{a}}$ diterima dan $\mathrm{H}_{\mathrm{o}}$ ditolak. Hasil penelitian ini juga sesuai dengan penelitian Atin Yulaifah (2001) yaitu "Pengaruh Budaya, Social, Pribadi dan Psikologis Terhadap Keputusan Nasabah Dalam Memilih Bank Syariah" dimana dari hasil penelitian di peroleh nilai thitung $\geq \mathbf{t}_{\text {tabel }}$ yaitu $-3,223 \geq 1,985$ dan nilai sig $\leq \alpha$ yaitu $0,002 \leq 0,05$.

Menurut (sunyoto, fathonah, 2015:137) psikologis merupakan ilmu yang mempelajari tentang prilaku dan kondisi jiwa manusia. Pilihan pembelian seseorang dipengaruhi oleh empat faktor psikologis utama yaitu motivasi, persepsi, pengetahuan, serta kepercayaan dan pendirian.

Suatu perangkat proses psikologis berkombinasi dengan karakteristik nasabah tertentu untuk menghasilkan proses keputusan, indicator yang paling dominan dari variabel psikologis adalah persepsi. Pihak bank dalam hal ini memberikan gambaran positif kepada para nasabah untuk dapat mempengaruhi keputusan. 


\section{KESIMPULAN DAN SARAN}

\section{Kesimpulan}

Faktor budaya tidak berpengaruh terhadap keputusan nasabah dalam memilih Bank Syariah Mandiri KCP Tajur. Hal ini dapat dilihat dari hasil uji parsial (uji t) pengaruh variabel budaya terhadap variabel keputusan nasabah, faktor ekstrinsik menjadi penyebab variabel budaya mengalami perubahan keputusan nasabah.

Faktor psikologis berpengaruh terhadap keputusan nasabah dalam memilih Bank Syariah Mandiri KCP Tajur. Hal ini dapat dilihat dari hasil uji parsial (uji t) pengaruh variabel psikologis terhadap variabel keputusan nasabah, faktor intrinsik dari variabel psikologis mempunyai pengaruh sangat kuat terhadap keputusan nasabah dalam memilih Bank Syariah Mandiri Tajur.

Faktor budaya dan psikologis secara bersama-sama berpengaruh terhadap keputusan nasabah dalam memilih bank syariah. Hal ini dapat dilihat dari hasil uji simultan (uji f) pengaruh variabel budaya dan psikologis terhadap variabel keputusan nasabah.

\section{Saran}

Variabel budaya yang tidak memiliki pengaruh yang positif dan sigifikan terhadap keputusan nasabah dalam penelitian ini bisa saja disebabkan karena pergeseran budaya dari serangkaian tata nilai, persepsi dan preferensi masyarakat. Oleh karena itu penulis menyarankan agar bank bisa mengikuti perubahan budaya tersebut dengan melihat sudut pandang dan selera masyarakat saat ini.

Pada penelitian ini variabel psikologis memiliki pengaruh yang positif dan signifikan terhadap keputusan nasabah. Indikator yang paling dominan dalam variabel ini adalah persepsi. Persepsi terbentuk berdasarkan informasi yang diterima seseorang. Semakin positif informasi maka persepsi yang dimiliki akan semakin baik, oleh karena itu penulis menyarankan kepada Bank Syariah Mandiri KCP Tajur untuk lebih meningkatkan kegiatan promosi dan sosialisasi yang berkaitan dengan kegiatan bank untuk membentuk persepsi positif kepada para calon nasabah.

Dilihat dari hasil uji simultan (uji f) dimana secara bersama-sama variabel budaya dan psikologis memiliki pengaruh positif dan signifikan terhadap variabel keputusan nasabah sebesar 50,5\% dengan sisanya 45,5 \% yang bisa saja dipengaruhi oleh variabel lain yang tidak ada dalam penelitian ini, penulis menyarankan pihak bank agar memperhatikan variabel yang tidak ada dalam penelitian ini untuk lebih mendapatkan gambaran strategi pengembangan yang baik untuk Bank Syariah Mandiri KCP Tajur kedepannya. 


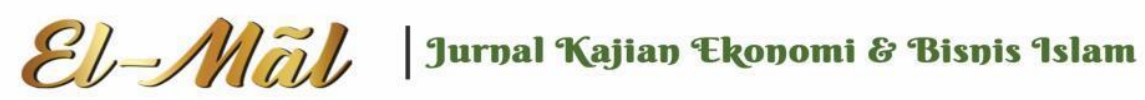

Vol 2 No 1 (2019) 89-110 P-ISSN 2620-295 E-ISSN 2747-0490

DOI: $1047467 /$ elmal.v2i1.316

\section{DAFTAR PUSTAKA}

Siti Umi Hanik, Jati Handayani (2014). Keputusan Nasabah Dalam Memilih Perbankan Syariah, JABPI, Vol. 22, No. 2, hlm. 193-194.

Abdurrahman. 2006. Rapor Merah Bank Syariah Kritik Atas Fatwa Produk Perbankan Syariah. Cetakan 4, Bogor: Al Azhar Perss

Abdurrahman, maman dan Sambas Ali Muhidin. 2011. Panduan Praktis Memahami Penelitian. Bandung: CV Pustaka Setia.

Algifari. 2000. Analisis regresi (teori kasus dan solusi). Yogyakart: BPFE

Amirullah. 2002. Prilaku Konsumen. Yogyakarta: Graha ilmu.

Antonio, Muhammad Syafi'i. 2001. Bank Syariah dari Teori ke Praktik. Jakarta:

Gema Insani

Arbi Syarif. 2003. Mengenal Bank dan Lembaga Keuangan Non Bank. Djambatan

Ferdinand, Augusty. 2006. Metode Penelitian Manajemen. Semarang: Badan Penerbit Universitas Diponegoro

Ghozali, Imam. 2013. Aplikasi Analisis Multivariate Dengan Program IBMM SPPS 21. Semarang: Badan Penerbit Universitas DiPonegoro

J. Salusu. 2006. Pengambilan Keputusan Strategik Untuk Organisasi Publik dan Organisasi Non Profit. Jakarta: Grasindo.

Kotler, Philip, dan Kevin Lane Keller. 2009. Manajemen Pemasaran. Jilid 2, edisi Ketiga Belas, Terjemahan Bob Sabran, MM. Jakarta: Erlangga.

Marimin. 2004. Teknik dan Aplikasi Pengambilan keputusan Kriteria Majemuk. Retrieved Desember 10, 2016, from http://books.google.co.id/books.htm

Schiffman, L.G, dan Leslie Lazar Kanuk. 2008. Perilaku Konsumen. Jakarta: PT Indeks Group Gramedia

Setiadi, Nugroho J. 2003. Perilaku Konsumen. Jakarta: Prenada Media.

Simamora Bilson. 2008. Memenangkan Pasar dengan Pemasaran Efektif dan Profitabel. Jakarta: PT. Gramedia Pustaka Utama

Sudarsono Heri. 2003. Bank Dan Lembaga Keuangan Syariah. Yogyakarta: Ekonisia Sugiyono. 2009. Metode Penelitian Kuantitatif, Kualitatif dan R\&D. Bandung: Alfabeta. Sumitro Warkum. 2001. Asas-Asas Perbankan Islam Dan Lembaga-Lembaga Terkait BMI \& Takaful Di Indonesia. Jakarta: PT Raja Grafindo Persada

Sunyoto, Danang dan Fathonah E.K. 2015.Manajemen Pemasaran Jasa. Yogyakarta: CAPS (Center For Academic Publishing Service).

Swastha, Basu dan Irwan. 2001. Manajemen Pemasaran Modern. Yogyakarta: Liberty Swastha Basu. 2000. Manajemen Pemasaran Modern. Edisi Kedelapan. Yogyakarta: Liberty 


\section{Cl, Pl/TIV I Jurnal Kajian Ekonomi \& Bisnis Islam}

Vol 2 No 1 (2019) 89-110 P-ISSN 2620-295 E-ISSN 2747-0490

DOI: 1047467/elmal.v2i1.316

Engel, Blackwell, dan Miniard. 1994. Perilaku Konsumen. Retrieved Desember 10, 2016, from http://books.google.co.id/books.htm

J. Salusu, 1996. Pengambilan Stratejik. Retrieved Desember 10, 2016, from http://books.google.co.id/books.htm

Aeni Wahyuni. 2013. Pengaruh Budaya, Psikologis dan Kepribadian Terhadap Keputusan

Nasabah Dalam Memilih Pembiayaan Murabahah Pada BMT Bina Ummat Mandiri Tambang. Universitas Islam Negri Sultan Syarif Kasim

Atin Yulaifah. 201. Pengaruh Budaya Sosial, Pribadi dan Psikologis Terhadap Keputusan

Nasabah Dalam Memilih Bank Syariah. Universitas Islam Negri Syarif Hidayatullah Jakarta

Damayanti Mayasaroh. 2014. Analisi Faktor-Faktor Yang Mempengaruhi Keputusan Nasabah Dalam Memilih Bank Syariah. Universitas Islam Negri Sunan Kalijaga

Rafif Mandana. 2015. Pengaruh Pribadi, Sosial, Kebudayaan dan Psikologis Dalam Pengambilan Keputusan Nasabah Memilih Produk Perbankan Syariah. Universitas Narotama Surabaya 